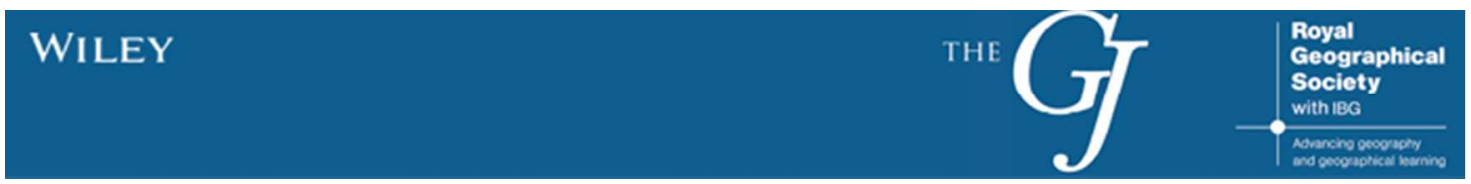

\title{
What Defines a River? Modelling the interplay between physical and social driving factors in characterizing the waterways in Chile
}

\begin{tabular}{|r|l|}
\hline Journal: & The Geographical Journal \\
\hline Manuscript ID & GJ-RP-Feb-2018-0020 \\
\hline Manuscript Type: & Regular Paper \\
\hline Keywords: & rivers, landscape perception, regionalism, Chile, mixed methods \\
\hline Abstract: & $\begin{array}{l}\text { The categorization of natural landscape features places a socialized and } \\
\text { ordered lens on the landscape. In the case of natural waterways, it creates } \\
\text { a regional hydrologic vocabulary, based in physical processes and cultural } \\
\text { history. This study uses the unique combination of hydrological and cultural } \\
\text { characteristics found in Chile to determine the degree to which local } \\
\text { waterway classifications of waterways as rivers (rí in Spanish) provides } \\
\text { insights to the cultural role in perceiving and describing such important } \\
\text { landscape elements. The results indicate that waterway classification is } \\
\text { strongly influenced by different regional cultural perspectives, which are } \\
\text { also affected by their regional climates. This variety of hydrologic } \\
\text { vocabularies presents distinct zones of waterway classification throughout } \\
\text { Chile, with implications of these differences affecting territorial planning, } \\
\text { water management, and even international relations. }\end{array}$ \\
\hline
\end{tabular}




\section{Introduction}

Social definitions of our surroundings influence and predispose us to viewing a physical landscape of continua as a landscape of categories of objects (Linton, 2010). In the case of waterways, there is no generally accepted scientific definition for what distinguishes between different categories of waterways (i.e., rivers, creeks, brooks, streams, etc.). The general naming convention is that rivers are the largest form of waterway, but even this rule is not universal, as temperate creeks can easily be larger than desert rivers. Indeed, the classification of a waterway is a local and inherited description relative to the largest regional waterway that fits cultural expectations of the idea of a river to its landscape. These determinations often include the utility of a waterway, especially in contexts of transport (Mauch \& Zeller, 2008; Oliver, 2010) or as borders (Dillehay, 2014; Hill, 1965; Miller Klubock, 2014; Rosenblitt B. \& Sanhueza B., 2010; St John, 1994). Furthermore, significant historical events and religious rituals taking place around specific rivers can elevate a waterway's visibility, contributing to the classification of particular small waterways of cultural significance as rivers (Linton, 2010; Peppard, 2013).

While comparative size within an area generally determines waterway classification in many places, the potential for neighboring hydrologic basins to be vastly different sizes means that large basins generate far larger waterways than is physically possible in far-smaller, neighboring basins. A good example of this can be found in California, where the San Joaquin River basin $\left(40,404 \mathrm{~km}^{2}\right)$ dwarfs the neighboring Russian River basin $\left(3,846 \mathrm{~km}^{2}\right)$, with similarly large differences in resulting hydrologic regimes. 
From a purely geomorphological perspective, the hydrological network is the set of channels draining a basin. In the upper basin, channels are generally steeper and narrower than in lowland reaches, as they receive less water and they are usually confined by valley geometries. These uppermost portions of the network are often referred to as colluvial reaches (Wohl, 2014), and are usually shaped by mass wasting phenomena, such as debris or hyperconcentrated flows. In contrast, downstream channels, with shallower slopes and higher and more regular discharges (although not necessarily perennial), are shaped by fluvial processes and are called alluvial reaches (Church, 2006). The boundary between colluvial and alluvial processes depends on climate, land use, and type of substrate, and it can be identified empirically as a function of local slope and drainage area (Montgomery \& Dietrich, 1989). However, although scientific assessment can identify the initiation of the channel head and stream head using physical characters of the reaches and drainage area (Henkle, Wohl, \& Beckman, 2011), the way in which waterways immediately downstream of the boundary between colluvial and alluvial processes are classified rarely conforms to scientific terms and descriptions of hydrological processes.

Throughout this paper, we will use the terms río, estero, and quebrada to refer to the waterways in Chile. As a linguistic outlier within Hispano-America, Chile uses different classifications than found in other Spanish-speaking countries. Although arroyo is quite commonly used in Latin America as a translation of stream or creek, in Chile, the term is barely used (Figure 2C). Instead, the equivalent term is estero, despite this term referring to still-water areas, like drowned river mouths, wetlands, or lagoons, in other Latin American countries. The other major term, quebrada, is generally used to refer to any intermittent waterway, regardless 
of its size or geomorphological characteristics (Figure 2). Outside of Chile, quebradas could refer to only intermittent systems or to perennially flowing waters (as is the case in Colombia and Venezuela). Analogous patterns of regional category preferences been described in the United States (Watkins, 2011) and Great Britain (Cheshire, 2011), showing strong historical influences in both regions.

\section{Objective of the Paper}

This paper will use the unique combination of hydrological and cultural characteristics found in Chile to determine the degree to which local classification of waterways as being a river (rí in Spanish) provides insights to the cultural role in perceiving and describing such important elements of the landscape. This paper will divide the nation of Chile into different regions using four different systems, based on latitude, history, climate, and a hybrid of climate and history. A probabilistic model is generated for each region to determine the predictive strength of waterway classification within that region. These models are then applied outside the region in order to determine the utility of that model in describing waterways outside the region in which the model was developed. If there is an underlying "national-level" logic to waterway classification, then a model developed in one region extend beyond that region, since it would use the same inherent logic. If, however, waterway classifications are regional, and fail to map to some national-level logic, then the models developed for one region will show significant failure rates outside of that region.

\section{The Physical and Cultural Contexts of Chile}


Chile represents an ideal setting to evaluate the patterns associated with waterway classification, because of a number of unique physical features. Specifically, all waterways flow from east to west, meaning there are no leeward/windward effects to address, and given the great height of the Andean range, the communities between Chile (on the Western slope) and Argentina (on the Eastern slope) had comparatively little direct historical contact. Furthermore, the size of most Andean basins is of the same order of magnitude. In fact, the similarity of basin size across the country means that climate differences drive the character of each hydrologic network. Indeed, the nation's north-to-south expanse covers 64 degrees of latitude, encompassing several different climate zones (INE, 2006). This allows an opportunity to examine the role that climate plays in the classification of waterways.

Being dominated by the presence of the Andean range, Chilean waterways are generally short and steep. As to rainfall, runoff increases from North to South. Waterways in the North are generally ephemeral, and runoff is generated by summer rainfall. The hydrological regime in basins in central Chile is determined by snow- and glacier-melt in spring and summertime, whereas towards the southern part of the country, the regime is progressively more dominated by rainfall (see (Valdes-Pineda et al., 2014) for details on Chilean hydrology).

Chile includes a variety of socially distinct regions, whose constitution has primarily rotated around the institution of southern and northern borders and the expansion of the country in both directions at different historical stages. Rivers have generally served as boundaries for the national territory in its different phases of expansion (Rosenblitt B. \& Sanhueza B., 2010; St John, 1994). At the time of Spanish invasion, Aymara, Atacameños (today known mainly as Likan Antai), and Diaguita groups occupied the Andean highlands in today's 
Northern Chile, and the coast was occupied by the Chango people (Hidalgo, 2004). These groups shared exchange networks, and during the 15th century had come under the influence of the Incan empire (Jones, 1999). Incan expansion had ended at the Maule River (current Central Chile) as the result of resistance by Mapuche and other southern groups who retained their independence (Dillehay \& Gordon, 1988). Although the Spanish made several incursions into Mapuche territory, the occasional Spanish expedition into Patagonia had little effect on indigenous groups there (Alacaluf, Onas, Selknam and Yamanes) until the 19th century (Jones, 1999).

The first incursions of the Spanish army into Mapuche territory date back to 1540, as part of a military campaign to occupy the region south of Peru (Collier, 2004, p. 3). The occupation of the Southwestern Andes anticipated the foundation of the Captaincy General of Chile, an administrative division of the Spanish empire under the Viceroyalty of Peru, with its capital in Santiago. The Spanish crown did not establish an exact northern border of the Captaincy, which later resulted in several controversies with Bolivia over the establishment of a frontier between the two recently independent countries in the $19^{\text {th }}$ century (Collier, 2004, $p$. 127). The eastern border of the Captaincy generally coincided with the Andes and separated it from the Viceroyalty of the Río de la Plata (modern-day Argentina). The southern border of the Captaincy was established following a failed Spanish invasion of Mapuche territories during the War of Arauco, which started in 1551 and formally concluded in 1641 with the Treaty of Quilin (Dillehay, 2014, p. 4). This treaty established the Biobío River as the border between the Spanish crown and sovereign Mapuche lands (Bengoa, 2000), and this area came to be known as la Frontera (Miller Klubock, 2014). Although the Captaincy theoretically extended to the 
Straits of Magellan, the Spanish exercised no direct control south of the Biobío, with the exception of a few settlements on the Chiloe Archipelago. Over the following centuries, the inhospitable Atacama Desert in the north and the Mapuche territories to the South came to encapsulate "Chile Central" at the time of independence in 1810.

The historical extension of Chile during Spanish rule was fixated by early cartographic representations. The most famous is the Tabula Geographica Regni Chile, reproduced in 1646 by the Jesuit chronicler Alonso de Ovalle (de Ovalle, 1646) and is regarded as the first map of Chile (Figure 1A). Although the map incorporates territory uncharted by Spanish surveyors, it illustrates how cartographic knowledge focused on colonized territory (Rosenblitt B. \& Sanhueza B., 2010, p. XXVIII), with very little topographic and topological detail in less settled areas. Significant to the present discussion, Chile Central was a region mapped through a relatively stable topographic dictionary during colonial times until independence in 1810 (for example, Figure 1B). Following independence, Chile's borders remained largely as they were during colonial rule, with the Salado River and Biobío Rivers being the most commonly accepted northern and southern borders for Chile, although Bolivian claims to the north were disputed (St John, 1994, p. 2).

In the second half of the $19^{\text {th }}$ century, Chile's borders radically changed following expansions northward and southward. Attracted by the prospect of the emerging mining industry in the Atacama Desert to the north, the Chilean army launched a military campaign against Bolivia and Peru, known as the War of the Pacific (1879-1884). Territorial disputes following occupation ended formally in 1929 with the Treaty of Lima, which set Arica as the 
northernmost town of Chile (Skuban, 2007, p. 208), with the majority of the Lluta River basin falling in Chilean territory.

Expansion of Chile's southern border was publicly justified as a project of civilization and pacification of the Mapuche region, which was experiencing clashes between settlers and the indigenous population, following land redistribution favoring European immigrants. Military occupation began in 1866, when Chilean troops crossed the Biobío River (Di Giminiani, 2018). Confrontations ended in 1884 with the annexation of Mapuche territories and the confinement of populations into reservations (Bengoa, 2000). Chile's control over their new territories which connected their holdings in Chile Central through to their presence on Chiloe Archipelago - was ensured by a rapid influx of settlers and miners.

A different pattern of occupation and topographic formalization unfolded in Patagonia, which was not exempt from territorial contestations. For much of its history following Spanish discovery, Patagonia was represented as empty space in different media, including cartography (Nouzeilles, 1999, p. 42). The lack of state presence came to be perceived by governmental actors as a threat to sovereignty and gradually became the focus of modern cartographic and topographic research.

The history of Chile basically created four regions of Chilean identity and expansion: Cultural Chile, which constitutes the political and cultural heart of the country, extending north and south to the old borders of the Captaincy General of Chile. The land to the north used to be a part of Bolivia, but - due to its aridity - was also sparsely populated. The land immediately to the south had been Mapuche territory; with borders that were fiercely defended for centuries 
against first the Incas and then the Spaniards. The land further south, Patagonia, was the most recently explored and settled by Europeans, filling in the blank areas of old maps.

\section{Methods}

Two major pieces of analysis were conducted. The first used physical variables to determine the distribution of waterway types along the colluvial-alluvial continuum, in order to evaluate the degree of concordance between process-based and socially influenced definitions. The second piece used topographic, hydrologic, and climatic variables to develop mathematical predictive models along different regional boundaries to define and predict what watercourses are likely to be defined as a "river," both within and between different regional boundaries.

Spatial data on named waterways across Chile was obtained from the Chilean General Water Directorate (Dirección General de Agua, DGA). Waterways conforming to the major categories of natural channels - quebrada, estero, and río - were extracted for consideration. In QGIS (QGIS Development Team, 2015), all contiguous waterway units with the same name were joined in order to more easily determine the downstream end of each named waterway. Waterways were assigned to four different zonation schemas: 10-degree latitude zones, Köppen climate zones (Peel, Finlayson, \& McMahon, 2007), zones of historical significance, and Chilean climate zones (Valdes-Pineda et al., 2014).

The mouth of each waterway was the chosen point to measure channel width, since it would be an equivalent measurement location for all waterways in the study. Google Earth was used for conducting these measurements. 
Since we were measuring the active channel width of waterways using Google Earth, we were unable to include many dry channels in Central and Northern Chile that were categorized as quebrada.

Following Henkle, et al. (Henkle et al., 2011), we determined the local slope and upstream basin area for each measured active channel location used in the study. The relationship between basin area and local slope was used to determine the position of the channel within the colluvial-alluvial continuum to determine how the terms "río," "estero," and quebrada relate to geomorphological processes within Chile (Henkle et al., 2011).

Since different regions appeared to use distinct means of distinguishing between quebrada and "estero," prior to model generation, all waterways were reclassified as being río or "not río" to provide a binary definition, against which logistic regressions could be generated. Then, for each categorization method (latitude zones, Köppen climate zones, historic zones, and Chilean climate zones, Figure 6A-D), a logistic regression model was generated for each region in SAS Studio (SAS Institute Inc., Cary, 2011) using channel width to predict waterway classification.

Since rivers are characterized by more than their channel widths, additional logistic regression equations were generated using a stepwise methodology for each region of each categorization method. These multiple logistic regression equations provide the opportunity of including climate- and topography-related factors that are important in generating local hydrological regimes.

Geographic were obtained from WorldCLIM (Hijmans, Cameron, Parra, \& Jones, 2005), and the variables used in generating the fully parameterized models were mean annual 
temperature, maximum temperature in the warmest month, coldest temperature in the coldest month, average temperature in the wettest quarter, average temperature in the driest quarter, annual precipitation, precipitation during the wettest month, precipitation during the driest month, and seasonality of precipitation. The variables related to temperature are associated with snow accumulation, melting, and evapotranspiration. Biophysical variables related with precipitation are associated with the amounts and seasonal intensities of precipitation. Both of these play important driving roles in hydrologic regimes (Jaeger, Montgomery, \& Bolton, 2007; Montgomery \& Dietrich, 1989). In addition to these biophysical variables, a number of hydrologically significant physical variables (Leopold, 1994) - total upstream area, stream order, distance to river mouth, altitude - were generated from the geographic datasets and provided for potential inclusion. Similar to the channel-width predictive models, these multiplevariable logistic regressions were used to generate multi-zonal predictions of waterway type in order to determine the extents of model functionality, both in-zone and out-of-zone.

Using the derived models, the likelihood of each waterway in the dataset being classified as río was calculated. All waterways where the calculated likelihood was greater than 50\% likelihood were classified as "río," while all others were classified as "not río." Then, the percentage of correctly categorized channels within each zone was calculated to determine the model accuracy within that zone. Values of $50 \%$ indicate that the model fared no better than a 50-50 chance. Values above 70\% are generally considered "reasonable" predictions, those above $80 \%$ are considered "good" predictions, while those above $90 \%$ indicate a "very good" capability of prediction in medicine and parasitology (Brooker, Hay, \& Bundy, 2002; Zweig \& Campbell, 1993). 


\section{Results}

Boxplot assessments conducted of the distributions of systems classified as quebrada, estero, and rio show that the basin areas of quebradas and esteros are not statistically different, while the basin areas associated with ríos are larger than esteros, but not larger than quebradas (Figure 3A). However, when looking at total precipitation in the basin (which acts as a proxy for the amount of annual runoff), esteros and ríos are not significantly different from each other, but overall quebradas included in this study are significantly smaller than either esteros or ríos (Figure 3B).

Assessments were conducted on 3,298 named waterways throughout the entire length of Chile (Figure 5D \& E). The total area for Chilean basins was more heavily associated with whether it was exohreic Andean system. The sizes of Andean basins ranged from $3,400 \mathrm{~km}^{2}$ (Lluta River) - 33,570 km² (Loa River), and the three largest basins (Loa, Biobío, and Baker) are widely dispersed across the country (mouth latitudes at $23.43^{\circ} \mathrm{S}, 36.81^{\circ} \mathrm{S}$, and $47.79^{\circ} \mathrm{S}$, respectively). Widths of waterways classified as río generally increased from north to south, with average widths of $10.9 \mathrm{~m}$ in the far north $\left(<20^{\circ} \mathrm{S}\right.$ latitude zone) to a minimum average width of $7.4 \mathrm{~m}$ between $20^{\circ}$ and $30^{\circ} \mathrm{S}$ to a maximum average width of $44.6 \mathrm{~m}$ among ríos between $40^{\circ}$ and $50^{\circ} \mathrm{S}$, before narrowing a lot to $20.2 \mathrm{~m}$ in the far south ( $>50^{\circ} \mathrm{S}$ latitude zone). The widest widths of ríos were 2,672 and $666 \mathrm{~m}$, corresponding to the mouths of the Biobio and Rapel Rivers, respectively. In addition to generally becoming broader, the overall number of waterways in general and the number of ríos in particular also increased from north to south. In the far north, there are 69 waterways (25 ríos), while in the far south, there are 190 
waterways (108 ríos). The area with the lowest density of waterways was in the $20^{\circ}-30^{\circ}$ latitude zone, with 76 total waterways and 63 ríos (Figure 6A).

The slope-area assessments of basins of various sizes, measured at the Pacific Ocean indicate that all waterways are characterized geomorphologically as lying within the zone of alluvial hydrological regime. When these waterways are segregated by their classification, ríos are clustered, mostly apart from the quebradas and esteros, which overlap a lot (Figure 4).

Across all models, the average within-zone correct prediction rate using channel width was $73.10 \%$, indicating the importance of channel width in the determination of waterway classification. At the national level, the predictive model based solely on channel width correctly predicted $75.35 \%$ of waterway classifications. The best predictive strength was seen in the $20^{\circ}-30^{\circ} \mathrm{S}$ latitude zone $(85.53 \%$ correct $)$, while the worst was seen in the cold semi-arid Köppen climate zone (58.82\% correct).

Within each zonation system, the within-zone predictive capacity was stronger than or roughly equivalent to out-of-zone predictions, with some notable examples, namely the coolsummer Mediterranean climate zone, the mild tundra climate zone, and the $>50^{\circ} \mathrm{S}$ zone, which all had at least one out-of-zone predictive result that was roughly $10 \%$ stronger than the inzone result (Table 1).

Across all models, the average within-zone correct prediction rate of the multiple logistic regression models was $78.63 \%$, indicating a general improvement of within-zone prediction across all zones. In nearly all cases, the within-zone predictive power was better than out-of-zone predictive power. The only major discrepancy in this trend was in the $>50^{\circ} \mathrm{S}$ latitude zone. Only the models for the cold semi-arid and the cool-summer Mediterranean climate 
zones omitted channel width as a variable, indicating the general strength of channel width in predicting waterway classification, even for predictive models that could draw upon several other variables. Also, the cold desert climate zone model was the only one with a single factor (channel width; Table 1).

\section{Discussion}

Throughout Chile, the slope-area assessment of the waterways indicates that all the points included in this study conform to alluvial (although not necessarily permanent) reaches (Figure 4). The category río falls easily within the physical forms typical of alluvial systems. This is unsurprising, since the term describes the sediment transport of systems characterized by flowing waters, either ephemeral or permanent. To extend this further, estero falling within the region of alluvial regimes (albeit being generally smaller than ríos) is not surprising, since estero is used in Chile to refer to perennial waterways that are smaller than ríos. The interesting point is that quebrada also falls within the alluvial regime.

Geomorphology and hydrology indicate that alluvial systems function differently from colluvial systems (Leopold, 1994; Montgomery \& Dietrich, 1989). However, the term quebrada - which best approximates colluvial systems - only has a weak distinction from alluvial systems - both of which are well described by estero and río. Given this, quebrada is of little use in anticipating the physical impacts of different waterways during times when they have flowing water. Indeed, during the floods of Northern Chile in 2017, the general news coverage and political discussion was about "activated quebradas" (i.e., quebradas with flowing water) 
(Cooperativa.cl, 2015; t13, 2017). Furthermore, many interviews and discussions would rely on the categorization of quebrada to explain the state changes of these flooded systems.

Indeed, two major quebrada systems that suffered from significant flooding during the 2017 floods - Quebrada Totoral (Figure 2) and Quebrada Chañaral (Figure 7) - are both shown to lie well within the alluvial type of waterway. Their general lack of water has meant that construction projects often treat them as if they were no more fluvially active than upland, colluvial waterways. Indeed, it is common in the north to see roads running through dry channels (Figure 2 \& Figure 7), with significant consequences for the connectivity of settlements when flows return to the channel, and the roads are destroyed. In short, the categorization of quebrada is focused on ephemerality and not geomorphological processes, and this provides little predictability as to the comparative levels of effect that occur when there are flows.

In general, though, impacts caused by the disconnect between scientific and social perspectives of river function are confined to the arid north of the country. As one moves south, waterways with perennial flows become increasingly dominant, and the interplay between physical and socio-historical forces on waterway categorization is more complicated than the ephemerality or permanence of running waters.

In assessing the accuracy of the predictive models, we first examine the relative predictive power of channel width in correctly categorizing waterways. The overall strength of the channel-width models were pretty high across all four zonation systems, with in-zone accuracy ranging from $52.87 \%$ (Norte Chico) to $85.53 \%\left(20^{\circ}-30^{\circ} \mathrm{S}\right.$ latitude zone). Furthermore, a number of out-of-zone models channel-width models showed strong predictive power. 
It is clearly true that ríos become larger from north to south, being roughly six times larger between the latitude zones with the narrowest $\left(20^{\circ}-30^{\circ} \mathrm{S}\right)$ and the widest $\left(40^{\circ}-50^{\circ} \mathrm{S}\right)$ río channel widths. However, the strengths of these latitude zones do not follow any cultural or physical contexts, and they are also highly correlated with the "warm-summer Mediterranean" and "temperate oceanic" Köppen climate zones (discussed below). Furthermore, unless we make the presumption that waterway classification is independent of cultural contexts, latitudinal zonation based on arbitrary 10-degree cut-offs is a highly unlikely explanatory mechanism. Therefore, while longitude is strongly associated with overall trends in the question of waterway classification, it is a highly unlikely means by which waterway classifications are based.

The strongest factor that defines the diversity of hydrologic regimes in Chile is the local climate (Valdes-Pineda et al., 2014). Indeed, what one sees as a longitudinal gradient in Chile is a physical representation of a climatic gradient, with arid deserts in the far North and sub-polar tundra in the far South. Therefore, if one assumes that waterway classification is driven by the same factors that define the physical properties of a region's waterways, climatic zonation should produce consistently strong within-zone models. Indeed, the models for warm-summer Mediterranean (75.35\%) and temperate oceanic (80.23\%) climates show the strongest withinzone models. However, the cool-summer Mediterranean (66.67\%) and mild tundra (67.71\%) climate zones all have stronger out-of-zone models. Both of these climate zones are noncontiguous within Chile (Figure 6B), and their low predictive power implies that they are crossing regions with inherently different waterway classifications. In contrast, most models of contiguous climate zones show strong within-zone predictive power, except the cold semi-arid 
zone (58.82\%). The very low predictive power of the cold semi-arid zone is likely due to a very small sample size that covers the area of northern Chile where waterways are scarce.

The patterns seen in model accuracy with climate models indicates that waterway classification is not necessarily strongly based on climate, despite it being a fundamental factor in defining hydrologic regimes.

Examining waterway categorization between the major zones of Chilean historic expansion shows the strength of cultural continuity within each of these zones. We make the assumption that each historical zone shares a general Spanish-speaking cultural context that was generated and stabilized over generations, prior to inclusion into Chile. Unlike national identities - which tend to be shared at national scales (Minkov \& Hofstede, 2012) - landscape descriptions tend to remain rooted in the cultural contexts of the past (Cheshire, 2011; Watkins, 2011).

The Cultural Chile ( $80.38 \%$ accuracy) zone is the cultural heart of Chile, and represents the area of the Captaincy General of Chile. To the north, "Old Bolivia" (69.88\% accuracy) represent captured territory, primarily from Bolivia, following the War of the Pacific. The contrast in accuracies between these two areas is stark, with strong within-zone predictive power in Cultural Chile.

South of Cultural Chile are the Mapuche Lands (76.34\% accuracy) and Patagonia (77.48\% accuracy). The comparatively late exploration of these areas, and the use of scientific methodologies when mapping them, created a distinct pattern of waterway classification that is more complex than the results imply. What's more the term quebrada re-emerges in Patagonia, despite it disappearing as one passed through the central part of Chile (Figure 5). 
However it is clear that history is quite strong in describing the patterns of waterway classification across Chile. However, we must also examine the strength of the hybrid system that mixes climate and history.

If we examine the concordance with climate types, in the arid Norte Grande, the major underlying factor that determines whether a waterway is considered a río appears to be whether it has water throughout the year. In this part of Chile, there are no channels that are designated as estero (Figure 5); the only designations are quebrada and río, regardless of size or geomorphologic potential. Even in this arid landscape, channel width proves to be a surprisingly strong predictive factor in-zone; the Norte Grande channel-width model is effectively out-ofzone.

In the semi-arid region of the Norte Chico, the predictive power of channel width drops to near uselessness (53\% correct prediction), which is partially explained by the paucity of channels with flowing water, even in the more humid, southern extent, of this zone.

From Chile Central to the south, there is generally strong predictive power in the channel width models (i.e., greater than $70 \%$ correct prediction). However, there is similarly strong out-of-zone predictive power as well, but if we look at the physical variables used to augment within-zone predictive power through the multiple logistic regression models, we see that these models use distinct sets of physical variables. The model from Chile Central include parameters related with temperature, while the model in Zona Sur includes precipitation parameters. Furthermore, while both models include a factor for the precipitation seasonality, this factor is negatively associated in the Mediterranean climate of Chile Central, and positively associated in the temperate climate of Zona Sur. Higher precipitation seasonality implies 
stronger differences between wet and dry seasons. Therefore, in the drier Chile Central, it is less likely that a channel is predicted to be a río when the difference between wet and dry season is large, which make sense, given the importance of rain and snow in defining the seasonal flow of rivers in this zone (Valdes-Pineda et al., 2014). In contrast, in the wetter Zona Sur, the prediction is increased as seasonality increases, which can be partially explained by the positive correlation between seasonality, mountain snowfall, and river size in this zone.

The fully parameterized model for Zona Austral is different yet again, since it includes a strong negative association altitude (i.e., a greater chance of being categorized as río at lower elevations), in addition to precipitation seasonality and temperature-related variables. It is worth noting that altitude is only ever found to be a predictor of a waterway categorization at this extreme end of Chile.

The interaction between the physical river processes and the socially defined categorizations of those processes on the landscape provide local and regional rationales that impose a mental order on the landscape. A waterway is a río, because it is one of the larger waterways in the region, regardless of whether there are esteros that eclipse it in size in another region of the country. Similarly, a quebrada is defined as such in northern Chile, because it rarely has water flowing in it, while in Patagonia, a quebrada is defined as having more hillslope and smaller size than an estero. Furthermore, esteros simply don't exist in the northern landscape, but dominate the southern landscape.

The implications of these regional social categorizations is that each historically common region shows a strong tendency to share implicit understandings of how physical forces generate things classified as quebradas, esteros, and ríos, but these socially implicit definitions 
do not always transfer across regions, despite being part of the same nation (Table 1). In that way, we see that the implicit ways that ríos are defined in the arid north are not translatable to the Mediterranean center, the temperate south, or the sub-polar and mountainous Patagonia. Furthermore, the historical contexts of each region - vis a vis entry into Chilean identity - also create dissociations between different regions, with the arid north carrying a nomenclature and waterway classification system more akin to modern-day Peru than to Central Chile, and Patagonia showing a method of naming strongly based around scientific precepts of the mid19th century. However, despite tacitly agreed-upon local uses of a common, local hydrologic vocabulary, the implicit understandings and expectations of local hydrological function associated with a particular hydrologic vocabulary - do not transfer well to questions of governance at the national level, nor does centralized governance based on implicit and local definitions translate well from core to periphery. It is into this milieu that water governance, landscape conservation, cultural associations with landscape, and applied science all fall.

\section{Conclusions and Implications}

The regionality of hydrologic vocabularies means there is no consistent underlying definition for waterways across a nation governed by a highly centralized system. This creates gaps in how environmental laws and regulations conceive of the natural world, and on how hydrological systems function locally. Using the example of quebradas, the classification of all dry and intermittent natural channels as quebradas in the arid north, regardless of their geomorphological character, can contribute to poor territorial planning, especially when large quebradas become "activated," and function geomorphologically as torrential ríos, because 
that is how these systems physically function (Figure 4). Indeed, even if quebradas are sometimes mentioned in regulations and laws, they are never explicitly defined.

Currently, article 97 of the Ley Orgánica of the Chilean Ministry of Public Works prohibits building construction in areas prone to flooding with a recurrence interval of ten years (BCN, 2014). However, many quebrada systems might be dry for over a decade, despite their potential for large and destructive flows in response to a rare frontal storm event. In these systems, the social awareness of flooding risks wane rapidly over time, especially where natural boundaries like floodplains, are blurred by informal settlements or when the local populations is characterized by migrants, who won't remember previous floods. This appears to be the case in many northern cities, where mining-driven economies attracted labor from around the country and abroad. The lowered social memory of flooding in Northern Chile, along with the poor land-use planning in flood-prone areas, often result in catastrophic events (Houston, 2006; Wilcox et al., 2016)(INE, 2016; ONEMI, 2017). In contrast, in areas where natural flooding is more common - as in Southern Chile - flood frequencies are sufficiently high to introduce and maintain flood risk in the minds of residents. Indeed, in Southern Chile, due to the interaction between the hydrology and social awareness, new construction is rarely concentrated along shorelines or floodplains.

Although the concept of río is perhaps the most concrete of the categories, its definition has become an important question in international relations. Passing over the Chile-Bolivia border, the Silala is a water course that Chile claims flows naturally into its territory (i.e., is a río), while Bolivia claims that the channel was artificially diverted into Chilean territory (i.e., is a canal), resulting in a dispute before the International Court of Justice (Meshel, 2017). The lack 
of a scientifically based definition for rio leaves the work of proving the categorization of this waterway to lawyers on each side.

The importance of reconciling legal, social, and scientific definitions of waterways is, in the end, and important task, since the lack of scientifically based definitions can lead to lacunae between different types of understandings, based on different, regionally developed hydrologic vocabularies. It is the authors' shared opinion that, despite these different vocabularies, it is unnecessary to generate a single, objective set of science-based definitions within the law, since such "scientization" of fundamental social constructs is often problematic, especially among communities that have such definitions imposed upon them (Das \& Tamminga, 2012; Ramakrishnan, 2003). However, successful science-based legal definitions of waterways can be accomplished through long-term public policy projects with strong sustained public engagement (Steinman, Nicholas, Seelbach, Allan, \& Ruswick, 2011), but this appears to be more of an exception than the rule, and these definitions only really function in legal and policy contexts as boundary objects (Lacy, 2013). Instead, harmonizing local hydrologic vocabularies formally (e.g., regionally defined regulations) or informally (e.g., creating translations between national legal and regional cultural realities) can help incorporate social conceptualizations of place within effective resource governance by translating national laws and regulations into existing local social and physical contexts (Linton, 2010; Scott, 1998).

The contexts and implications outlined in this paper are not limited to waterway classification, either in Chile or globally. The ways in which social and physical phenomena result in different classifications - and even different local vocabularies - of physical objects in nature can be seen in topography (France, 2008), forests (Hnatiuk, Tickle, Wood, \& Howell, 
2003), planets (Broughton, Sinatra, \& Nussbaum, 2013), and more. Understanding how natural and social forces define and organize each cultural and regional perspective of the physical world can help bridge different ways of knowing and interacting with that same physical world.

\section{References}

BCN. Coordinato y Sistemizado de la Ley N 15.840, de 1964 y del DFL. N² 206, de 1960 (2014). Chile, Chile.

Bengoa, J. (2000). Historia del pueblo mapuche: siglo XIX y XX. Santiago: Lom Ediciones.

Brooker, S., Hay, S. I., \& Bundy, D. A. P. (2002). Tools from ecology: Useful for evaluating infection risk models? Trends in Parasitology. https://doi.org/10.1016/S14714922(01)02223-1

Broughton, S. H., Sinatra, G. M., \& Nussbaum, E. M. (2013). "Pluto Has Been a Planet My Whole Life!" Emotions, Attitudes, and Conceptual Change in Elementary Students' Learning about Pluto's Reclassification. Research in Science Education, 43(2), 529-550. https://doi.org/10.1007/s11165-011-9274-x

Cheshire, J. (2011). Naming Rivers and Places. Retrieved December 20, 2015, from http://spatialanalysis.co.uk/2011/08/naming-rivers-and-places/

Church, M. (2006). Bed Material Transport and the Morphology of Alluvial River Channels. Annual Review of Earth and Planetary Sciences, 34(1), 325-354. https://doi.org/10.1146/annurev.earth.33.092203.122721

Collier, S. (2004). A History of Chile. Cambridge: Cambridge University Press. 
Cooperativa.cl. (2015). Región de Coquimbo: Activación de quebradas genera corte de rutas. Cooperativa.cl. Retrieved from http://www.cooperativa.cl/noticias/pais/tiempo/region-decoquimbo-activacion-de-quebradas-genera-corte-de-rutas/2015-10-19/134157.html Das, P., \& Tamminga, K. R. (2012). The ganges and the GAP: An assessment of efforts to clean a sacred river. Sustainability, 4(8), 1647-1668. https://doi.org/10.3390/su4081647 de Ovalle, A. (1646). Historica relacion del Reyno de Chile y de las misiones y ministerios que exercita en él la Compañía de Jesus. (F. Cavallo, Ed.). Rome: Biblioteca Nacional. Retrieved from http://www.memoriachilena.cl/602/w3-article-8380.html

Di Giminiani, P. (2018). Sentient lands: indigeneity, property and political imagination in neoliberal Chile. Tucson, AZ: University of Arizona Press.

Dillehay, T. D. (2014). The Teleoscopic Polity: Andean Patriarchy and Materiality (2014th ed.). Berlin, Heidelberg: Springer.

Dillehay, T. D., \& Gordon, A. (1988). La actividad prehispánica de los incas y su influencia en la Araucania. In La frondera del estado inca (Proceeding, pp. 215-234). Oxford.

France, R. (2008). A tale of two mountains: mountains in biblical spirituality. Rural Theology, 6(2), 117-125. https://doi.org/10.1179/rut_2008_6_2_005

Henkle, J. E., Wohl, E., \& Beckman, N. (2011). Locations of channel heads in the semiarid Colorado Front Range, USA. Geomorphology, 129(3-4), 309-319. https://doi.org/10.1016/j.geomorph.2011.02.026 Hidalgo, H. L. (2004). Historia Andina en Chile (Vol. 1). Santiago: Editorial Universitaria. Hijmans, R., Cameron, S., Parra, J., \& Jones, P. (2005). WorldClim-global climate data. ... Climate Surfaces for Global .... 
Hill, J. E. (1965). El Chamizal: A Century-Old Boundary Dispute. Geographical Review, 55(4), 510. https://doi.org/10.2307/212412

Hnatiuk, R., Tickle, P., Wood, M. S., \& Howell, C. (2003). Defining Australian forests. Australian Forestry, 66(3), 176-183. https://doi.org/10.1080/00049158.2003.10674909

Houston, J. (2006). The great Atacama flood of 2001 and its implications for Andean hydrology. Hydrological Processes, 20(3), 591-610. https://doi.org/10.1002/hyp.5926

INE. (2006). Compendio Estadístico. Síntesis geográfica Nacional.

INE. (2016). Medio Ambiente, Informe Anual 2016. Santiago, Chile, Chile. Retrieved from http://www.ine.cl/docs/defaultsource/publicaciones/2016/medio_ambiente_2016.pdf?sfvrsn=6

Jaeger, K. L., Montgomery, D. R., \& Bolton, S. M. (2007). Channel and perennial flow initiation in headwater streams: Management implications of variability in source-area size.

Environmental Management, 40(5), 775-786. https://doi.org/10.1007/s00267-005-0311-2

Jones, K. L. (1999). Warfare, Reorganization, and Readaptation at the Margins of Spanish Rule: The Southern Margin (1573-1882). In F. Salomon \& S. B. Schwartz (Eds.), The Cambridge History of the Native Peoples of the Americas (pp. 138-187). Cambridge: Cambridge University Press. https://doi.org/10.1017/CHOL9780521630764.004

Lacy, S. N. (2013). Assessing Michigan's 2008 Water Conservation Law: Scientific, Legal, and Policy Analyses. University of Michigan. Retrieved from http://hdl.handle.net/2027.42/102372

Leopold, L. B. (1994). A View of the River. Harvard University Press. Retrieved from http://books.google.com/books?id=QWDQ7ezcjbcC 
Linton, J. (2010). What Is Water?: The History of a Modern Abstraction. Vancouver: UBC Press.

Mauch, C., \& Zeller, T. (2008). Rivers in History: Perspectives on waterways in Europe and North America. (C. Mauch \& T. Zeller, Eds.). Pittsburgh, PA: University of Pittsburgh Press.

Meshel, T. (2017). A new transboundary freshwater dispute before the International Court of Justice. Water International, 42(1), 92-96.

https://doi.org/10.1080/02508060.2016.1249247

Miller Klubock, T. (2014). La Frontera: Forests and Ecological Conflict in Chile's Fronteir Territory (Radical Perspectives). Duke University Press Books.

Minkov, M., \& Hofstede, G. (2012). Is National Culture a Meaningful Concept? Cultural Values Delineate Homogeneous National Clusters of In-Country Regions. Cross-Cultural Research, 46(2), 133-159. https://doi.org/10.1177/1069397111427262

Montgomery, D. R., \& Dietrich, W. E. (1989). Source areas, drainage density, and channel initiation. Water Resources Research, 25(8), 1907-1918. https://doi.org/10.1029/WR025i008p01907

Nouzeilles, G. (1999). Patagonia as borderland : Nature, culture, and the idea of the state. Journal of Latin American Anthropology, 8(1), 35-48. https://doi.org/Article

Oliver, S. (2010). Navigability and the improvement of the river Thames, 1605-1815. Geographical Journal, 176(2), 164-177. https://doi.org/10.1111/j.1475-4959.2010.00354.x ONEMI. (2017). Informe Estadístico Anual de ONEMI Año 2016 -- N². Santiago, Chile. Retrieved from http://repositoriodigitalonemi.cl/web/bitstream/handle/2012/1784/InfEstAnualONEMI20 16. pdf?sequence $=6$ 
Peel, M. C., Finlayson, B. L., \& McMahon, T. A. (2007). Updated world map of the KöppenGeiger climate classification. Hydrology and Earth System Sciences, 11(5), 1633-1644. https://doi.org/10.5194/hess-11-1633-2007

Peppard, C. Z. (2013). Troubling waters: The Jordan River between religious imagination and environmental degradation. Journal of Environmental Studies and Sciences, 3(2), 109-119. https://doi.org/10.1007/s13412-013-0116-1

QGIS Development Team. (2015). QGIS Geographic Information System. Open Source Geospatial Foundation Project. https://doi.org/http://www.qgis.org/

Ramakrishnan, P. S. (2003). The Sacred Ganga River-based Cultural Landscape. Museum International, 55(2), 7-17. https://doi.org/10.1046/j.1350-0775.2003.00420.x

Rosenblitt B., J., \& Sanhueza B., C. (2010). Cartografía histórica de Chile (Tomo 41). Santaigo: Cámara Chilena de la Construcción, Pontificia Universidad Católica de Chile, Biblioteca Nacional de Chile. Retrieved from http://biblioteca.cchc.cl/DataFiles/25593-2.pdf

SAS Institute Inc., Cary, N. (2011). SAS. SAS Institute Inc., Cary, NC. Retrieved from www.sas.com/pt_br/home.html

Scott, J. C. (1998). Seeing Like a State: How Certain Schemes to Improve the Human Condition Have Failed. Yale University Press.

Skuban, W. E. (2007). Lines in the Sand: Nationalism and Identity on the Peruvian-Chilean Frontier. Albuquerque: University of New Mexico Press.

St John, R. B. (1994). The Bolivia-Chile-Peru Dispute in the Atacama Desert. Durham. Retrieved from https://www.dur.ac.uk/ibru/publications/view/?id=205

Steinman, A. D., Nicholas, J. R., Seelbach, P. W., Allan, J. W., \& Ruswick, F. (2011). Science as a 
fundamental framework for shaping policy discussions regarding the use of groundwater in the State of Michigan: A case study. Water Policy, 13(1), 69-86.

https://doi.org/10.2166/wp.2010.047

t13. (2017). Intendente de Atacama: "No hay riesgo de aluvión en la provincia de Chañaral." t13.cl. Retrieved from http://www.t13.cl/noticia/nacional/Intendente-de-Atacama-Nohay-riesgo-de-aluvion-en-la-provincia-de-Chanaral

Valdes-Pineda, R., Pizarro, R., Garcia-Chevesich, P., Valdes, J. B., Olivares, C., Vera, M., ... Helwig, B. (2014). Water governance in Chile: Availability, management and climate change. Journal of Hydrology, 519(PC), 2538-2567. https://doi.org/10.1016/j.jhydrol.2014.04.016 Watkins, D. (2011). Inundated with place names. Retrieved December 20, 2015, from https://derekwatkins.wordpress.com/2011/07/25/generic-stream-terms/

Wilcox, A. C., Escauriaza, C., Agredano, R., Mignot, E., Zuazo, V., Otárola, S., ... Mao, L. (2016). An integrated analysis of the March 2015 Atacama floods. Geophysical Research Letters, 43(15), 8035-8043. https://doi.org/10.1002/2016GL069751

Wohl, E. (2014). Rivers in the Landscape: Science and Management. Wiley-Blackwell.

Zweig, M. H., \& Campbell, G. (1993). Receiver-operating characteristic (ROC) plots: A fundamental evaluation tool in clinical medicine. Clinical Chemistry. https://doi.org/ROC; Receiver-Operating Characteristic; SDT; Signal Detection Theory 


\section{TABLES}

Table 1. Percent correct prediction by models based on purely channel width and a fully parameterized model. Results show both the in-zone percent of correct predictions, and the minimum, average, and maximum out-of-zone percent of correct predictions. The national model and the four different zonations are also reported. Percent correct prediction $\geq 70 \%$ are in bold.

\begin{tabular}{|c|c|c|c|c|c|c|c|c|c|}
\hline & \multirow[t]{2}{*}{ In-zone } & \multirow{2}{*}{\multicolumn{2}{|c|}{$\begin{array}{c}\text { Out-of-zone } \\
\text { Averag } \\
\text { e }\end{array}$}} & \multirow[b]{2}{*}{ Max } & $\begin{array}{l}\text { Full } \\
\text { In- } \\
\text { zone }\end{array}$ & \multicolumn{3}{|c|}{$\begin{array}{c}\text { Out-of-zone } \\
\text { Averag }\end{array}$} \\
\hline & & & & & & & Min & e & Max \\
\hline & & & & & & 76.58 & & & \\
\hline \multicolumn{2}{|c|}{ Nationwide model } & $75.35 \%$ & - & - & - & $\%$ & - & - & - \\
\hline \multirow{3}{*}{\multicolumn{2}{|c|}{$\mathrm{K} 21$}} & & 37.06 & 51.87 & 66.67 & 71.43 & 37.06 & 51.87 & 66.67 \\
\hline & & $71.43 \%$ & $\%$ & $\%$ & $\%$ & $\%$ & $\%$ & $\%$ & $\%$ \\
\hline & & & 19.49 & 32.26 & 45.71 & 82.35 & 56.90 & 63.34 & 75.00 \\
\hline \multirow{2}{*}{\multicolumn{2}{|c|}{$\mathrm{K} 26$}} & $58.82 \%$ & $\%$ & $\%$ & $\%$ & $\%$ & $\%$ & $\%$ & $\%$ \\
\hline & & & 35.29 & 62.43 & 79.75 & 76.65 & 44.12 & 63.40 & 73.79 \\
\hline \multirow{2}{*}{\multicolumn{2}{|c|}{ K32 }} & $75.35 \%$ & $\%$ & $\%$ & $\%$ & $\%$ & $\%$ & $\%$ & $\%$ \\
\hline & & & 41.18 & 61.63 & 79.55 & 74.27 & 22.85 & 50.93 & 75.00 \\
\hline \multirow{7}{*}{ 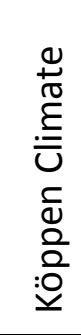 } & K33 & $74.27 \%$ & $\%$ & $\%$ & $\%$ & $\%$ & $\%$ & $\%$ & $\%$ \\
\hline & & & 41.18 & 61.36 & 73.62 & 86.39 & 51.43 & 62.32 & 71.48 \\
\hline & K35 & $80.23 \%$ & $\%$ & $\%$ & $\%$ & $\%$ & $\%$ & $\%$ & $\%$ \\
\hline & & & 46.93 & 59.63 & 74.29 & 87.50 & 23.53 & 48.69 & 70.87 \\
\hline & K36 & $66.67 \%$ & $\%$ & $\%$ & $\%$ & $\%$ & $\%$ & $\%$ & $\%$ \\
\hline & & & 44.12 & 62.45 & 75.85 & 78.29 & 52.94 & 66.35 & 79.19 \\
\hline & K62 & $67.71 \%$ & $\%$ & $\%$ & $\%$ & $\%$ & $\%$ & $\%$ & $\%$ \\
\hline \multirow{10}{*}{ 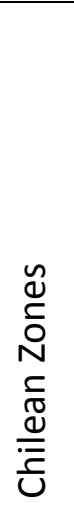 } & Norte & & 43.37 & 52.11 & 55.95 & 81.93 & 64.37 & 68.40 & 73.35 \\
\hline & Grande & $69.88 \%$ & $\%$ & $\%$ & $\%$ & $\%$ & $\%$ & $\%$ & $\%$ \\
\hline & & & 26.01 & 33.84 & 45.78 & 77.59 & 67.71 & 71.56 & 75.90 \\
\hline & Norte Chico & $52.87 \%$ & $\%$ & $\%$ & $\%$ & $\%$ & $\%$ & $\%$ & $\%$ \\
\hline & & & 44.83 & 64.70 & 78.19 & 89.19 & 33.25 & 51.10 & 63.22 \\
\hline & Chile Central & $79.49 \%$ & $\%$ & $\%$ & $\%$ & $\%$ & $\%$ & $\%$ & $\%$ \\
\hline & & & 44.25 & 64.53 & 80.13 & 77.30 & 46.55 & 59.20 & 80.86 \\
\hline & Zona Sur & $80.13 \%$ & $\%$ & $\%$ & $\%$ & $\%$ & $\%$ & $\%$ & $\%$ \\
\hline & & & 46.55 & 65.01 & 78.21 & 80.84 & 26.83 & 40.64 & 47.70 \\
\hline & Zona Austral & $74.70 \%$ & $\%$ & $\%$ & $\%$ & $\%$ & $\%$ & $\%$ & $\%$ \\
\hline
\end{tabular}




\begin{tabular}{|c|c|c|c|c|c|c|c|c|c|}
\hline \multirow{8}{*}{ 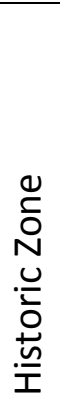 } & & \multirow[b]{2}{*}{$69.88 \%$} & 39.01 & 49.56 & 60.16 & 81.93 & 60.35 & 71.75 & 81.44 \\
\hline & Old Bolivia & & $\%$ & $\%$ & $\%$ & $\%$ & $\%$ & $\%$ & $\%$ \\
\hline & Cultural & \multirow{3}{*}{$80.38 \%$} & 54.22 & 64.93 & 76.54 & 79.96 & 54.22 & 62.99 & 74.40 \\
\hline & Chile & & $\%$ & $\%$ & $\%$ & $\%$ & $\%$ & $\%$ & $\%$ \\
\hline & Mapuche & & 62.65 & 69.08 & 75.29 & 77.13 & 54.22 & 63.98 & 79.00 \\
\hline & Lands & \multirow[t]{2}{*}{$76.34 \%$} & $\%$ & $\%$ & $\%$ & $\%$ & $\%$ & $\%$ & $\%$ \\
\hline & & & 55.42 & 67.46 & 79.85 & 81.37 & 42.17 & 59.75 & 71.37 \\
\hline & \multirow[t]{2}{*}{ Patagonia } & \multirow[t]{2}{*}{$77.48 \%$} & $\%$ & $\%$ & $\%$ & $\%$ & $\%$ & $\%$ & $\%$ \\
\hline \multirow{10}{*}{ 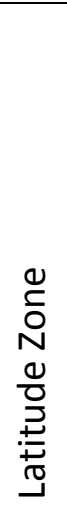 } & & & 50.00 & 57.24 & 63.69 & 75.36 & 50.00 & 57.24 & 63.69 \\
\hline & \multirow[t]{2}{*}{$<20^{\circ} \mathrm{S}$} & \multirow[t]{2}{*}{$75.36 \%$} & $\%$ & $\%$ & $\%$ & $\%$ & $\%$ & $\%$ & $\%$ \\
\hline & & & 27.11 & 39.92 & 59.47 & 90.79 & 43.68 & 64.75 & 76.03 \\
\hline & \multirow[t]{2}{*}{$20^{\circ}-30^{\circ} \mathrm{S}$} & \multirow[t]{2}{*}{$85.53 \%$} & $\%$ & $\%$ & $\%$ & $\%$ & $\%$ & $\%$ & $\%$ \\
\hline & & & 19.74 & 54.62 & 74.98 & 79.33 & 36.23 & 49.13 & 68.97 \\
\hline & \multirow[t]{2}{*}{$30^{\circ}-40^{\circ} \mathrm{S}$} & \multirow[t]{2}{*}{$79.76 \%$} & $\%$ & $\%$ & $\%$ & $\%$ & $\%$ & $\%$ & $\%$ \\
\hline & & & 19.74 & 55.81 & 79.71 & 80.63 & 43.68 & 52.44 & 59.42 \\
\hline & \multirow[t]{2}{*}{$40^{\circ}-50^{\circ} \mathrm{S}$} & \multirow[t]{2}{*}{$75.07 \%$} & $\%$ & $\%$ & $\%$ & $\%$ & $\%$ & $\%$ & $\%$ \\
\hline & & & 47.37 & 59.84 & 72.46 & 43.16 & 17.11 & 62.26 & 81.43 \\
\hline & $>50^{\circ} \mathrm{S}$ & $62.63 \%$ & $\%$ & $\%$ & $\%$ & $\%$ & $\%$ & $\%$ & $\%$ \\
\hline
\end{tabular}

Köppen climate zones: K21: cold desert, K26: cold semi-arid, K32: temperate oceanic, K33: subpolar oceanic, K35: warm-summer Mediterranean, K36: cool-summer Mediterranean, K62: mild tundra 


\section{FIGURE LEGENDS}

Figure 1. A) Reproduction of the Tabula Geographica Regni Chile showing the major rivers between Río Salado (to the left) and the Straits of Magellan (the channel between the mainland and Tierra del Fuego). Map taken from de Ovalle (1646, p. 521). Note, the map has been cropped to focus only on modern-day Chile. B) Reproduction of the Map of Chile by Ambrosio O’Higgins, year 1768, showing rivers between Río Copiapó and the Island of Chiloe. Map taken from Rosenblitt \& Sanhueza (2010).

Figure 2. (A) The local topologies of all the systems categorized as quebrada, (B) difference between the major dry channel of the Quebrada de Totoral (large dashed line) vs the smaller hillslope channels (thin dotted lines), with Highway C-322 crossing through the main channel. (Figure 2A derived from Google Earth; photo taken by author 1)

Figure 3. Distribution of sizes of A) basin area and B) total precipitation for basins classified as quebrada, estero, and río from across Chile.

Figure 4. Distribution of waterways, using the slope-area method, following Henkle et al. (2011) to determine the type of geomorphological channels are included in the study. Esteros shown as diamonds, quebradas as squares, and ríos as triangles. 
Figure 5. Spatial distribution of waterway classifications. Original data from the General Water Directorate: (A) ríos, (B) quebradas (red) and esteros (green), and (C) arroyos. Data used in this study: (A) ríos, (B) quebradas (red) and esteros (green).

Figure 6. Zonations used in the study. (A) Latitude-based zonation, (B) Köppen climate-systembased zonation, (C) historical and cultural zonations, and (D) the five Chilean climate and culture zones. Köppen climate-system codes: K21: cold desert, K26: cold semi-arid, K32: temperate oceanic, K33: subpolar oceanic, K35: warm-summer Mediterranean, K36: coolsummer Mediterranean, K62: mild tundra.

Figure 7. Photo of highway C500 running through the channel of Quebrada Chañaral. (Photo by author 1) 


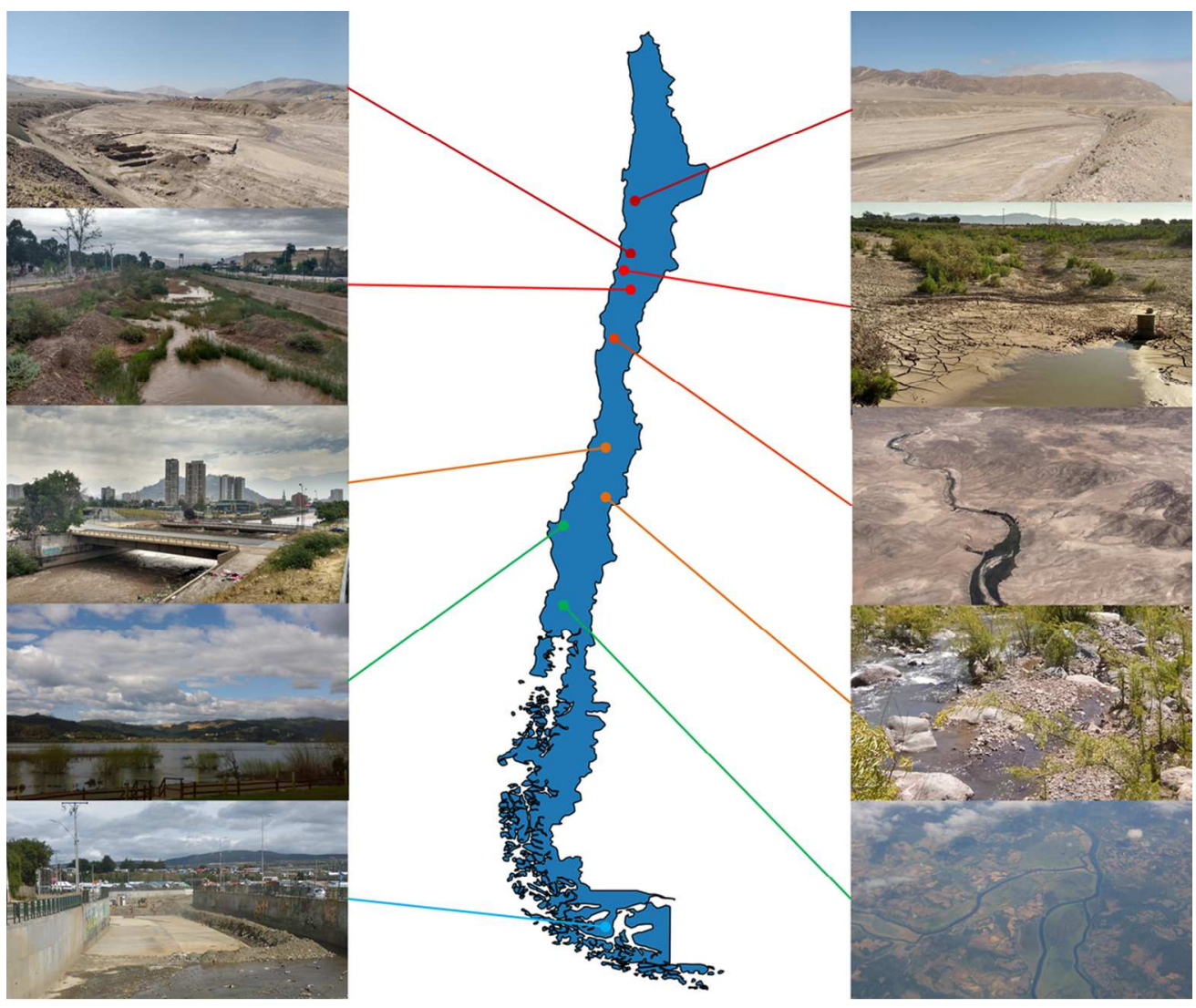

Graphical Abstract

$49 \times 41 \mathrm{~mm}(600 \times 600 \mathrm{DPI})$ 
Figure 1. A) Reproduction of the Tabula Geographica Regni Chile showing the major rivers between Río Salado (to the left) and the Straits of Magellan (the channel between the mainland and Tierra del Fuego). Map taken from de Ovalle (1646, p. 521). Note, the map has been cropped to focus only on modern-day Chile. B) Reproduction of the Map of Chile by Ambrosio O'Higgins, year 1768, showing rivers between Río Copiapó and the Island of Chiloe. Map taken from Rosenblitt \& Sanhueza (2010).

$99 \times 54 \mathrm{~mm}(300 \times 300$ DPI $)$ 
Figure 2. (A) The local topologies of all the systems categorized as quebrada, (B) difference between the major dry channel of the Quebrada de Totoral (large dashed line) vs the smaller hillslope channels (thin dotted lines), with Highway C-322 crossing through the main channel. (Figure 2A derived from Google Earth; photo taken by Shaw Lacy.)

$75 \times 86 \mathrm{~mm}(300 \times 300 \mathrm{DPI})$ 

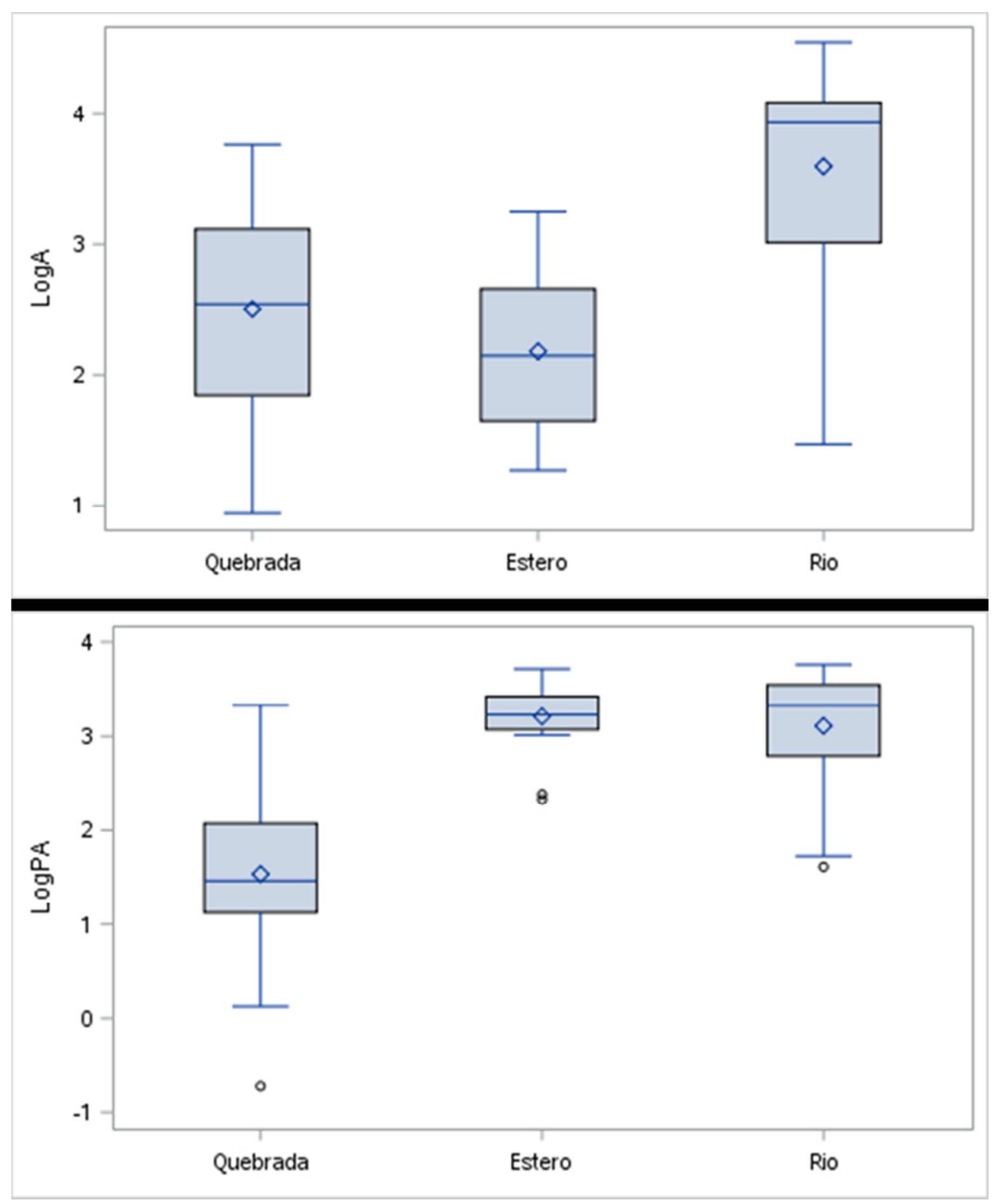

Figure 3. Distribution of sizes of A) basin area and B) total precipitation for basins classified as quebrada, estero, and río from across Chile.

\section{$63 \times 77 \mathrm{~mm}(300 \times 300$ DPI $)$}




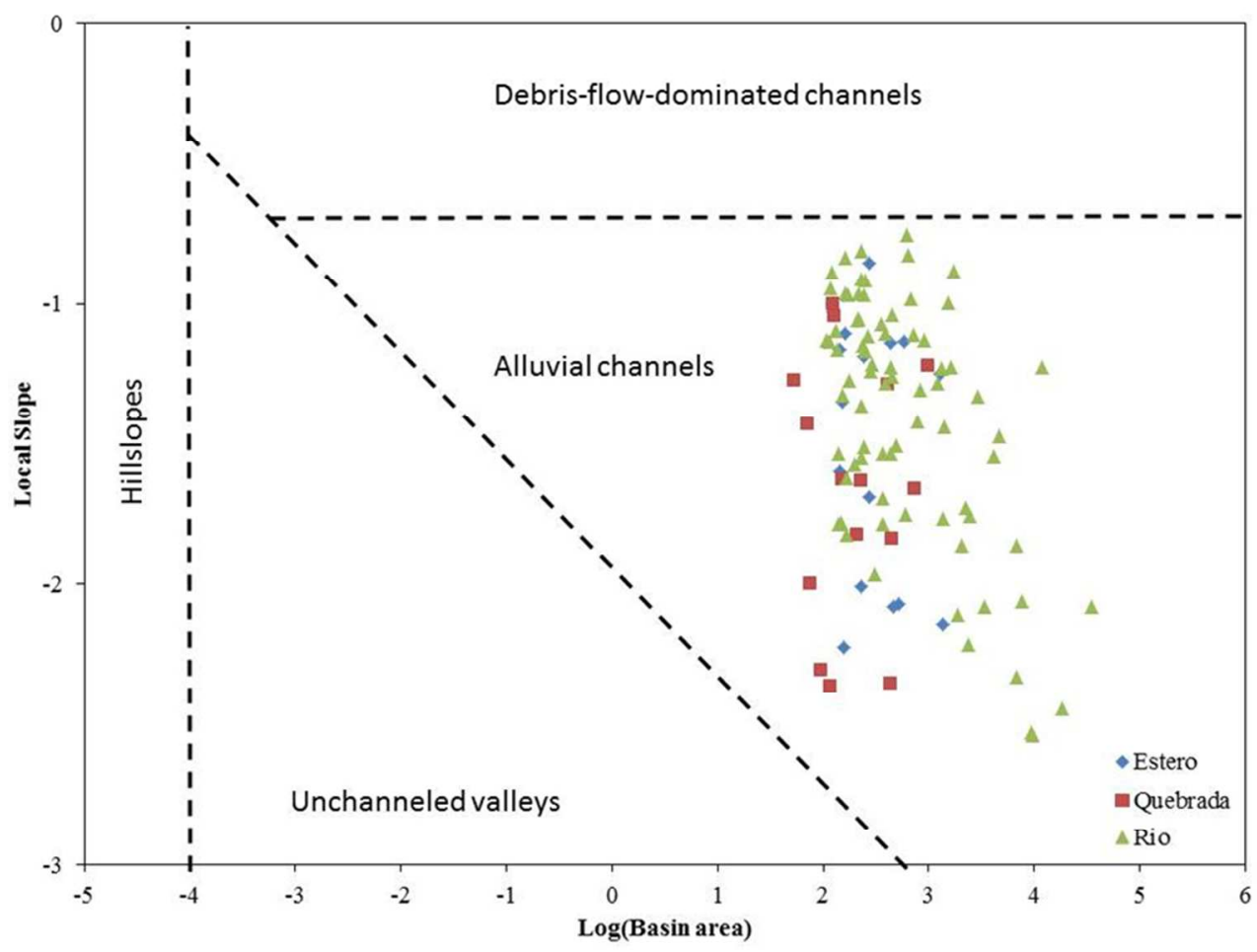

Figure 4. Distribution of waterways, using the slope-area method, following Henkle et al. (2011) to determine the type of geomorphological channels are included in the study. Esteros shown as diamonds, quebradas as squares, and ríos as triangles.

$79 \times 60 \mathrm{~mm}(300 \times 300 \mathrm{DPI})$ 

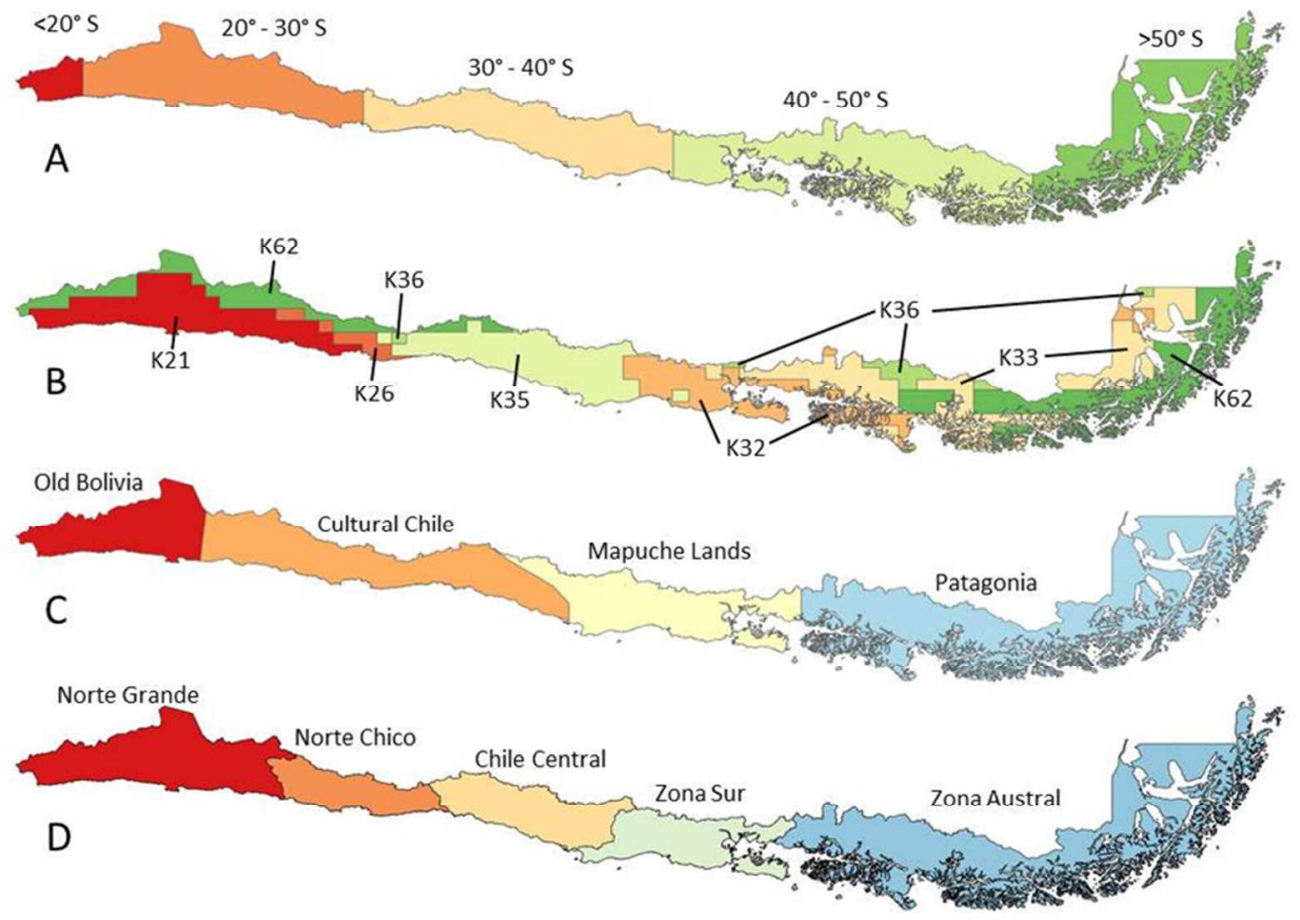

Figure 6. Zonations used in the study. (A) Latitude-based zonation, (B) Köppen climate-system-based zonation, (C) historical and cultural zonations, and (D) the five Chilean climate and culture zones. Köppen climate-system codes: K21: cold desert, K26: cold semi-arid, K32: temperate oceanic, K33: subpolar oceanic, K35: warm-summer Mediterranean, K36: cool-summer Mediterranean, K62: mild tundra. 


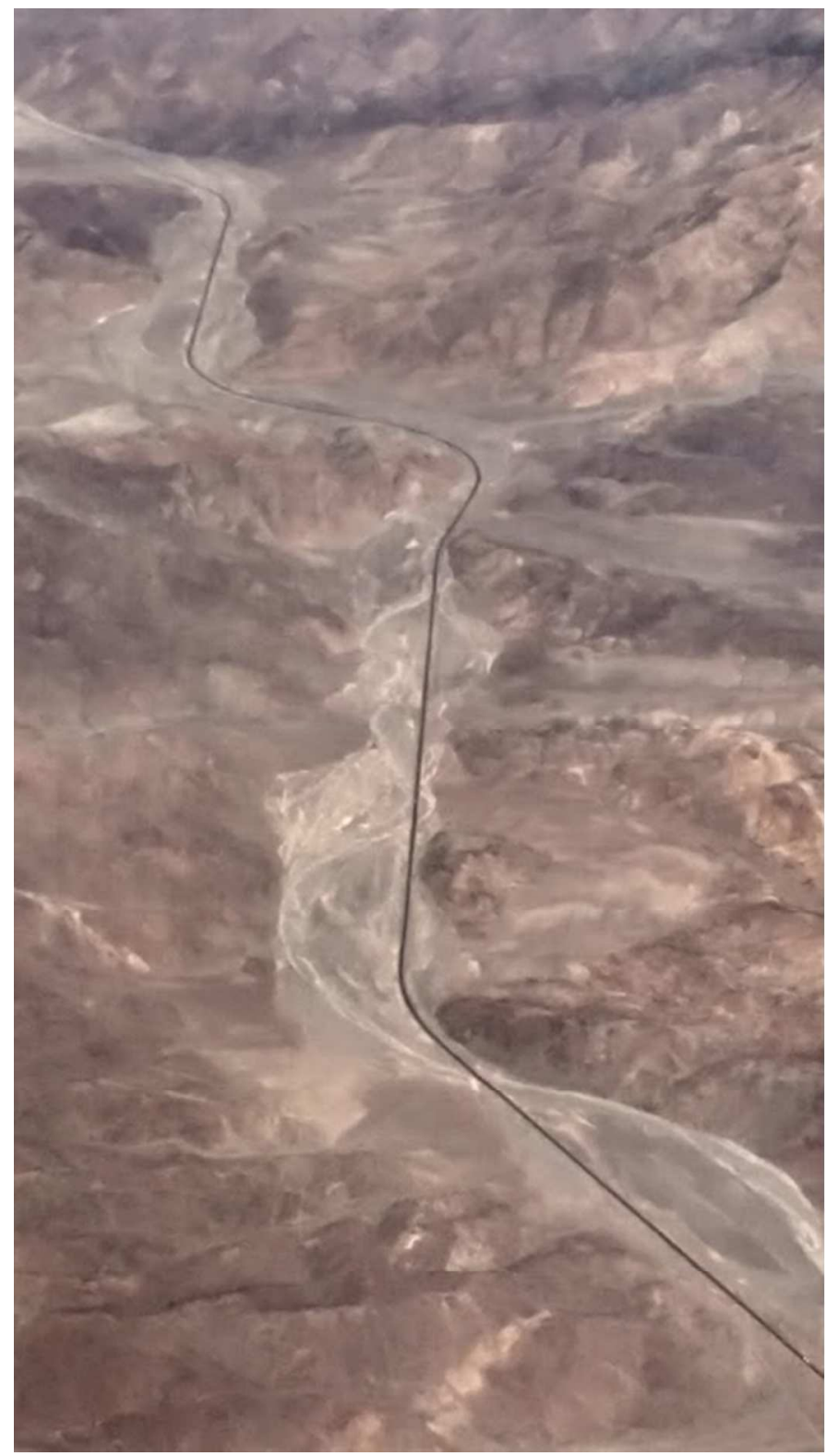

Figure 7. Photo of highway C500 running through the channel of Quebrada Chañaral. (Photo by Shaw Lacy) $44 \times 80 \mathrm{~mm}(300 \times 300 \mathrm{DPI})$ 